RACAR : Revue d'art canadienne

Canadian Art Review

RACAR

\title{
Exhibitions, Manifestos, and the Seventieth Anniversary of Refus global
}

\section{Ray Ellenwood}

Volume 44, numéro 1, 2019

URI : https://id.erudit.org/iderudit/1062156ar

DOI : https://doi.org/10.7202/1062156ar

Aller au sommaire du numéro

Éditeur(s)

UAAC-AAUC (University Art Association of Canada | Association d'art des universités du Canada)

ISSN

0315-9906 (imprimé)

1918-4778 (numérique)

Découvrir la revue

Citer ce compte rendu

Ellenwood, R. (2019). Compte rendu de [Exhibitions, Manifestos, and the Seventieth Anniversary of Refus global]. RACAR : Revue d'art canadienne / Canadian Art Review, 44(1), 99-105. https://doi.org/10.7202/1062156ar

Tous droits réservés (C) UAAC-AAUC (University Art Association of Canada | Association d'art des universités du Canada), 2019
Ce document est protégé par la loi sur le droit d'auteur. L’utilisation des services d'Érudit (y compris la reproduction) est assujettie à sa politique d'utilisation que vous pouvez consulter en ligne.

https://apropos.erudit.org/fr/usagers/politique-dutilisation/ 
Exhibitions, Manifestos, and the Seventieth Anniversary of Refus global

Ray Ellenwood

August 8, 2018, was the 7oth anniversary of the publication of Refus global, the manifesto of a multi-disciplinary group of Montreal artists called the Automatists, widely recognized as important avant-garde figures in the history of Canadian modernism. The story of the manifesto and its reception is quite well known: immediate official and public reaction was strongly negative because the manifesto was seen as dangerously anti-clerical. ${ }^{1}$ Gradually, however, Refus global and the activities of the group came to be recognized as constituting a crucial moment in the cultural history of the province. In 1959 and 1960 , the periodical Situations began the process of redemption by publishing a special number entitled "Refus global: dix ans après," followed by a posthumous celebration of the mentor of the group, visual artist Paul-Émile Borduas. Ten years later, in August, 1969, La barre du jour published an important special number entitled Les automatistes, with texts by and on the movement, the manifesto itself, and some of the signatories. No doubt stimulated by these anniversary celebrations, an exhibition entitled "Borduas et les automatistes, Montréal 1942-1955," opened in October, 1971, at the Galeries Nationales du Grand Palais in Paris and moved to the Musée d'art contemporain in Montreal in January of 1972. Following these first signs of broad, even international recognition, every ten years for almost half a century we have come to expect various kinds of celebrations-exhibitions, publications,

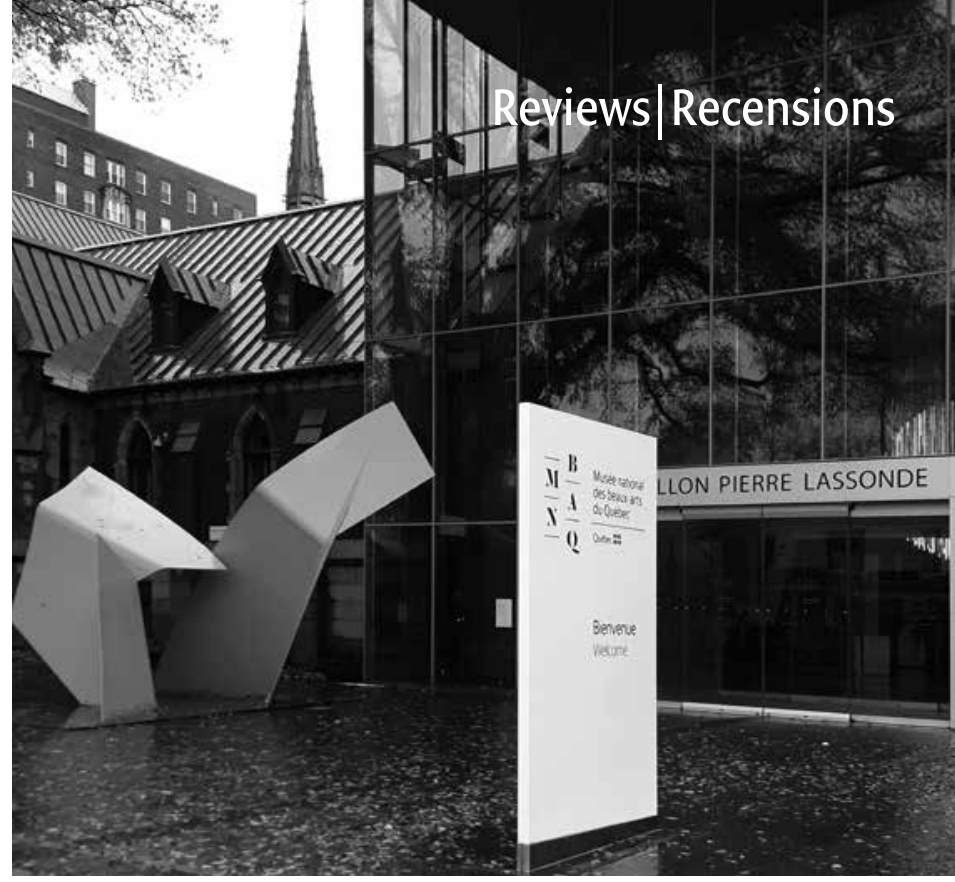

films, performances-commemorating Refus global and its adherents to the extent that some commentators have complained of "occultation." 2

Over the years, celebrations of the group and its manifesto have been at times personal and intimate, at times more academic, and at times highly public, government-sponsored and elaborate. ${ }^{3}$ The year 2018 was no exception, especially in Quebec, where the anniversary still has considerable meaning. Besides the several exhibitions I am about to describe, there was a series of lectures by Gilles Lapointe, professor at l'Université du Québec à Montréal, a prolific writer and editor of texts relating to Automatism. These were truly downtown events, with sell-out crowds despite a significant admission fee. The titles: «Borduas à visage découvert," "Les echos de Refus global d'hier à aujourd'hui," and "Les femmes et Refus global,» were obviously in keeping with anniversary celebrations. ${ }^{4}$ Lapointe also took part in a day-long colloquium and celebration of the man who has been, no doubt, the single most influential figure among researchers and writers on
Automatism: François-Marc Gagnon. ${ }^{5}$ The gathering heard presentations on Gagnon and his work from speakers such as Dominic Hardy, Laurier Lacroix, and Louise Vigneault.

I did not attend those events, but what follows is a brief account of some others I was able to witness during 2018, mostly in Montreal and Quebec, but also in Toronto. The observations are not objective (since I was an occasional participant) or complete (since my visits were limited in time while relevant events often took place over many days), but they can give some idea of the continuing impact of the Automatist manifesto on the way its signatories are presented as artists, especially in Quebec. Generally speaking, an invocation of the Automatist past could be a benefit to

Above Exhibition Marcel Barbeau en mouvement, Musée national des beaux-arts du Québec, from October 11, 2018 to January 6, 2019. View of entrance to the Pierre Lassonde Pavilion with Barbeau sculpture, Chant d'amours, 1990 (produced in 2018). Painted steel, $427 \times 594 \times 564 \mathrm{~cm}$. Coordinator: Martin Brisson, sculpteur. Production: Industries Océan, in collaboration with Fondation Marcel Barbeau. (c) Succession Marcel Barbeau/sodRAC (2019) Photo: Damien Gillot. 
the artist-signatories of Refus global, especially as their history and the manifesto became better known. But at times, as their methods changed and they moved away from the practices of the 1940s, an emphasis on retrospection could be seen as a distraction from their current work. This possible tension was never far from the surface in the exhibitions I visited. To establish a point of contrast, we might begin with some where the Automatist histories of the artists were scarcely mentioned.

\section{Solo Exhibitions}

La tendresse des nuages was a show mainly of works by Fernand Leduc at Galerie Catalogue in Montreal from August to November. ${ }^{6}$ It was a fine display of paintings and pastels from the 1950s through 2008, showing the end period of Leduc's gestural work (the style usually associated with the early history of Automatism), through the more structured "pavés," where colour is laid on in quite large, balanced areas, and into the "microchromies" of the 1970s, where such structures are covered by layer upon layer of very thin colour until a desired tone is reached. These monochromes are deceptive because each work resonates with cool or warm shades swimming beneath the surface, giving the lie to any notion of stability in colour or light. Interspersed with the paintings in this exhibition were quotations printed on the walls from letters written by Nicolas de Staël (an artist whom Leduc admired but never met), all relevant to de Staël's fascination with light and colour, and all relating astonishingly to the artworks and musings of Leduc himself. Nothing in the exhibition directly evokes the history of Automatism, or of Leduc's place therein. The subject here is the sublimity of light, which may have been Leduc's main obsession from the beginning but was most obviously so in his later works. As if to show how the subject is anything but new, the gallery included an "Annunciation" done in 1505 by the Dutch painter Jan Provoost, with delicate renderings of material and spiritual light. Hanging just across a corner of the room was a piece by Leduc I found particularly attractive: a medium-sized work entitled Souvenir. Impression Carrara (1987), an oil pastel on canvas. Leduc did a considerable number of oil pastels on paper that are among his most popular works, but few pastels on canvas. This one is predominantly white, with delicate tinting from under-colours and a rich texture provided by both the canvas surface and the all-over, fine strokes

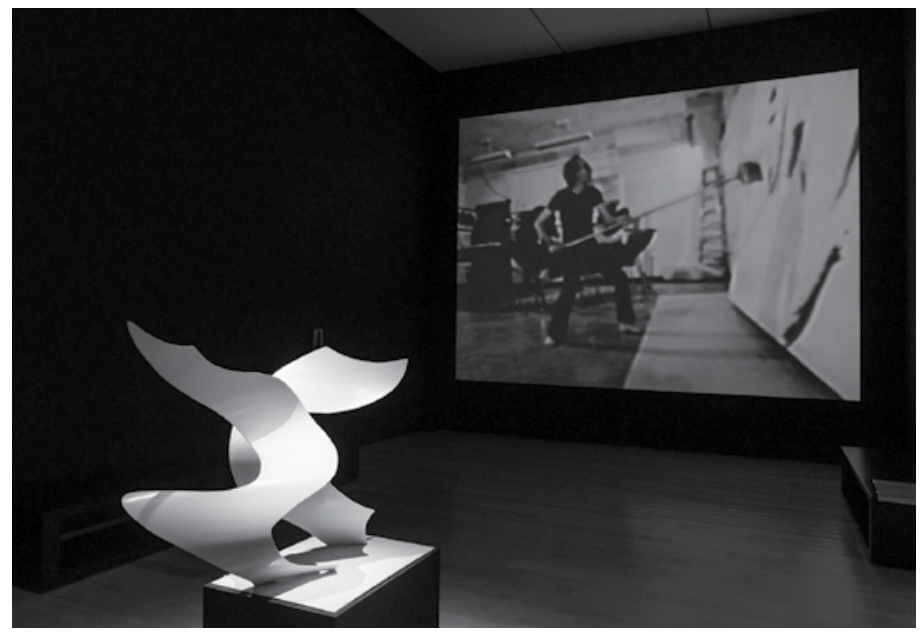

reflecting light in very subtle ways.

Some weeks later, a large and sumptuous retrospective entitled Marcel Barbeau: En mouvement opened at the Musée national des beaux-arts du Québec. ${ }^{7}$ We were told in the exhibition notes that this was the most important retrospective ever shown of the artist's work, a statement that hints at how Barbeau has not been treated generously over the years by public galleries in Quebec and the rest of Canada. Of all the painter-signatories of Refus global, he may be the least represented in art museums of his home province. Perhaps as a result, this was a very earnest exhibition, a teaching moment in art history, focussed on the development of the painter's ideas and methods over time, with scant attention paid to biographical or contextual/historical details (the catalogue makes up for this with its various essays on the artist and an excellent illustrated chronology).

Something this exhibition showed very well is the alternation between moments of abandon and control in Barbeau's work. There are the Automatist works of the mid-1940s and 1950s, recognized as perhaps the most advanced experiments in all-over gestural painting of the time. This changes to a more controlled minimalism in the $1960 \mathrm{~s}$ with a sometimes calligraphic line, followed by compositions with large areas of black and white confronting and balancing each other, unmoving. Then comes the period of meticulous works using colour and line bent to create optical movement, followed by carefully constructed and coloured formed canvases. The kinetic

Left. Exhibition Marcel Barbeau en mouvement Musée national des beaux-arts du Québec, from October 11, 2018 to January 6, 2019. Foreground: La puissance de l'espoir, 1985. Painted steel, $114.3 \times 121 \times 63 \mathrm{~cm}$. Musée national des beaux-arts du Québec collection, donation of Esperanza Schwartz (1988.118). (C) Succession Marcel Barbeau/sodRAC (2019). Photograph: (C) MNBAQ, Idra Labrie. Background: filmed painting/performance by Marcel Barbeau, ca. 1975. Photo: Idra Labrie. 




works, by the way, seemed to draw many people, especially the young. Those works in turn were followed by some very large drawings done with long-handled brushes, some of them "performed" in public, followed by the anaconstructions with their carefully composed and arranged geometric shapes in bright colours set against a monochrome background, and the "tachist" works of the later years. Of course, such a quick overview is far too schematic and over-simplified, but these movements were unmistakable and fascinating in the exhibition. Rhythm and music were important threads uniting the various moods of the show. Stockhausen was a major influence on Barbeau's minimalist drawings of the late 1950 and early 1960 s, and Stockhausen's music was playing softly where these drawings were shown.

When Barbeau returned to gestural painting about six years after his kinetic period, he did so in the company of dancers and musicians several times, in places like Caen, Montreal, and Toronto. ${ }^{8}$ In the last of the spacious, imposing rooms housing this exhibition viewers could study a very large black-and-white, exuberantly gestural drawing entitled Mouvement dusoir (1980), while looking past it through glass doors into a small room showing two films (1976 and 1977) where the artist could be seen creating similar works, dancing with a long
Left. Exhibition Françoise Sullivan, chorégraphie de la matière, Galerie Simon Blais, Montreal, October 10, 2018. Foreground, Océan, 1968. Plexiglas and metal. Background, corner of a painting from the Damiers series (2018). Photo: Guy L'heureux.

Bottom. Exhibition Les automatistes en trois temps, Galerie Michel Guimont, Quebec, from September 23 to October 23, 2018. Shown (L-R) are paintings by Fernand Leduc, Marcel Barbeau, Pierre Gauvreau. Photo: Galerie Michel Guimont.

brush in his hands, sweeping broad strokes onto a surface, accompanied by percussionists and fellow dancers. The setting of the new Pierre Lassonde Pavilion of the MNBAQ (which opened with the Mitchell/Riopelle exhibition at roughly this time last year) ${ }^{9}$ allowed ample space for all the exuberant movement and colour of Barbeau's work, and we were ushered in by a brightyellow, monumental sculpture seventeen feet high and nineteen feet wide, standing outside the main doors of the pavilion facing the Grande Allée. Entitled Chant d'amour, it was recently constructed after a maquette made by Barbeau in 1990.

of the eight exhibitions I saw, Françoise Sullivan (the renowned choreographer/dancer and visual artist, now in her 95th year) was represented in all the group shows as well as in two small solo exhibitions of her work that might almost have been

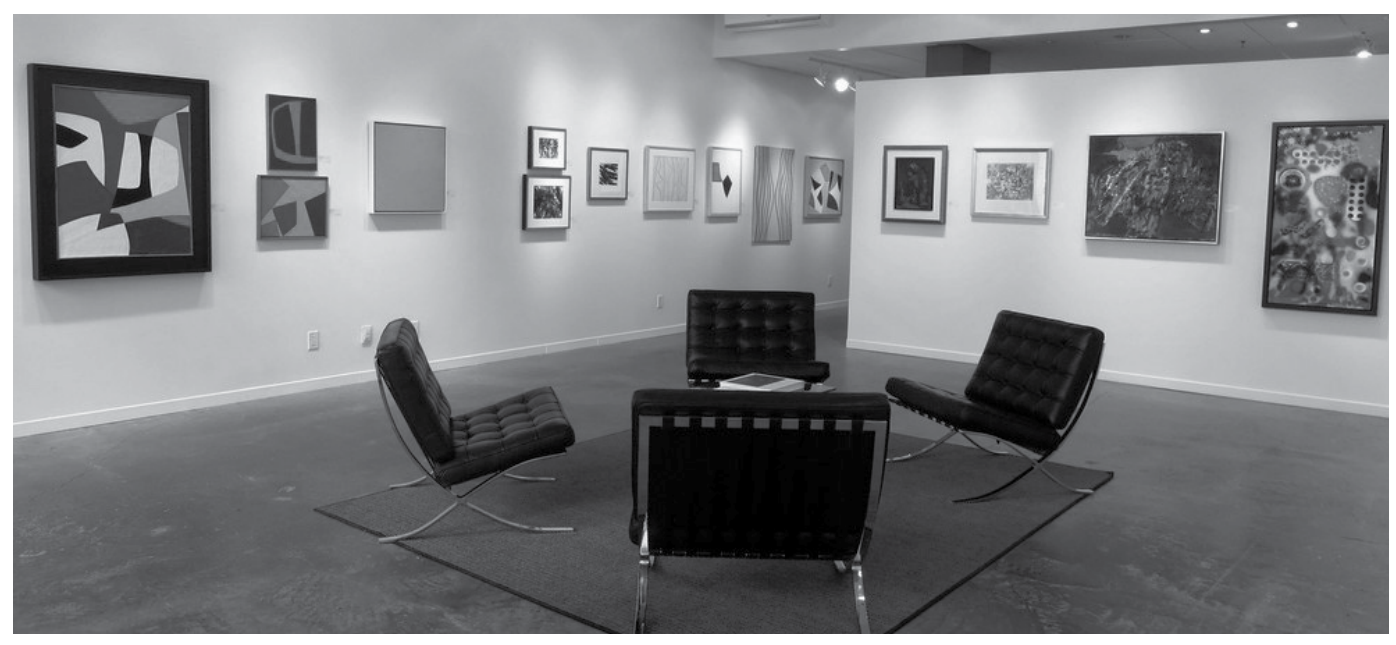


called satellite events to the large retrospective I will discuss later. The first of these, entitled Sullivan at the Modern, opened at the new modern. toronto gallery and ran from September 20 to November $17 .^{10}$ The show included a mini-overview of Sullivan's work, with the entrance hall of the gallery showing early works including photographs of the famous Danse dans la neige (1948) and of conceptual interventions in the Blasket Islands of Ireland (1978), as well as a fine tondo of 1980 and a pastel on paper of 1996 , both in dark tones and greys that showed well against rough concrete walls, while contrasting markedly with the bright works in succeeding rooms. The main emphasis was on paintings from 2005 to 2018 , showing Sullivan moving from the early monumental monochromes, through fragmentation of the space into irregular fields of colour in the Proportio series of 2015-16, to the surprising development of 2018, where multi-coloured, small rectangles begin to look like squares on a checker board, except that they are hand drawn and irregular, warping slightly in places to give optical illusions of movement. All of this worked well against the industrial concrete walls and polished concrete floors that reflected the paintings in fascinating ways. ${ }^{11}$ This was the only event in Toronto relevant to the Automatist anniversary, but here, as in the Leduc exhibition, the emphasis was on later work. Early history was only hinted at.

I had understood that another small exhibition of Françoise

Right. Exhibition Françoise Sullivan, Musée d'art contemporain de Montréal from October 20, 2018 to January 20, 2019. Paintings from the Vestiges (1992), Rouge (1997), and Damiers (2018) series. Photo: Richard-Max Tremblay.

Facing page. Exhibition Françoise Sullivan, Musée d'art contemporain de Montréal from October 20, 2018 to January 20, 2019. Sculpture from circa 1960-1969. Photo: Richard-Max Tremblay.
Sullivan's work at the Simon Blais Gallery in Montreal would be restricted to sculpture, but it also included three large, recent paintings, two from 2018, evidence of Sullivan's firm insistence that some of her most recent works be shown even in a retrospective context. ${ }^{12}$ The sculptures were mainly plexiglass pieces from 1966-68 and metal pieces from $1967-70$, the period when Sullivan returned to visual art after twentyyears devoted to choreography and dance. The metal sculptures ranged from harsh, angular pieces of rusted scrap metal, through painted or polished round shapes held in delicate equilibrium by angled armatures, all in marked contrast to the softly rounded, clear or coloured waves or coils in plexiglass. It was remarkable how these brightly coloured sculptures from the 1960 s seemed to echo the most recent paintings. But the biggest coup of the show was an assemblage piece with a large, clear, plexiglass coil about a metre long and twenty centimetres in diameter, resting on a dark blue base approximately one meter cubed. A striking apparatus that has not been shown before, it was supposed to be in an exhibition of minimalism at the Musée des beaux-arts in 1969 but was damaged in transport and has only recently been repaired. The dark blue metal base has a concave top large enough to hold the plexiglass coil and deep enough to allow it to roll, given a small push, from side to side of the concavity. As it rolls, the tube sets off coloured lights that shine through it from each end, amusing the child in all of us. These earlier and smaller Sullivan exhibitions were a fine complement to the major retrospective which arrived at the Musée d'art contemporain de Montréal later in theyear.

\section{Exhibitions Referencing the Group.} and the Manifesto

In contrast to the exhibitions mentioned so far, in which the history of Automatism played little or no part, there were others that made specific reference to, even foregrounded, the anniversary of Refus global. Among them were two small exhibitions held at the Simon Blais Gallery in Montreal ${ }^{13}$ and the Michel Guimont Gallery in Quebec City. ${ }^{14}$ For Refus global: 70 ans, the Blais gallery offered about twenty works by Automatist painters from different periods-a varied selection of mainly small pieces, some of which (notably a set by Pierre Gauvreau) had not been exhibited before. There were also a couple of display cases with a thoughtful selection of documents related to the movement. The Michel Guimont Gallery also offered a relatively small exhibition, suitable to the space available, but with large

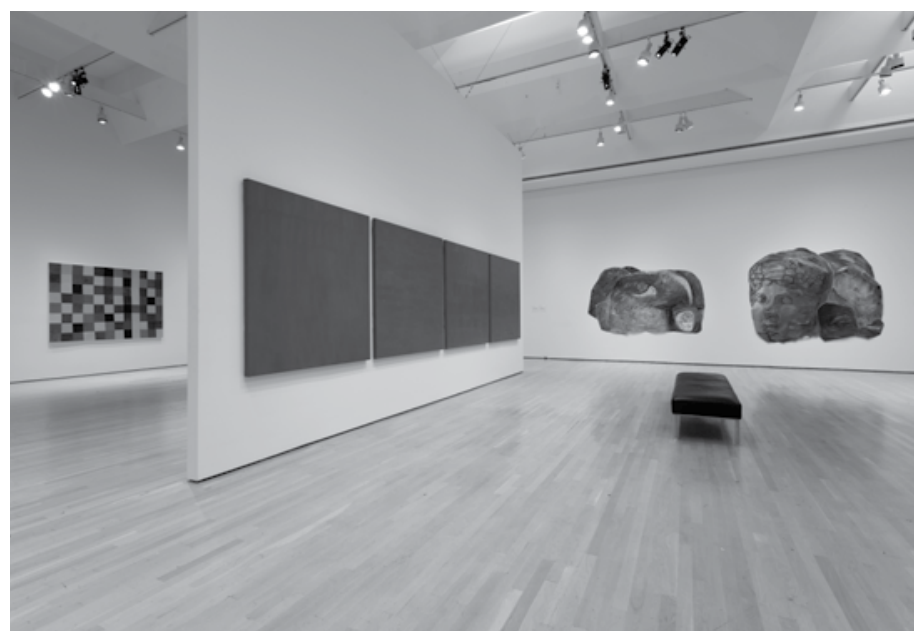




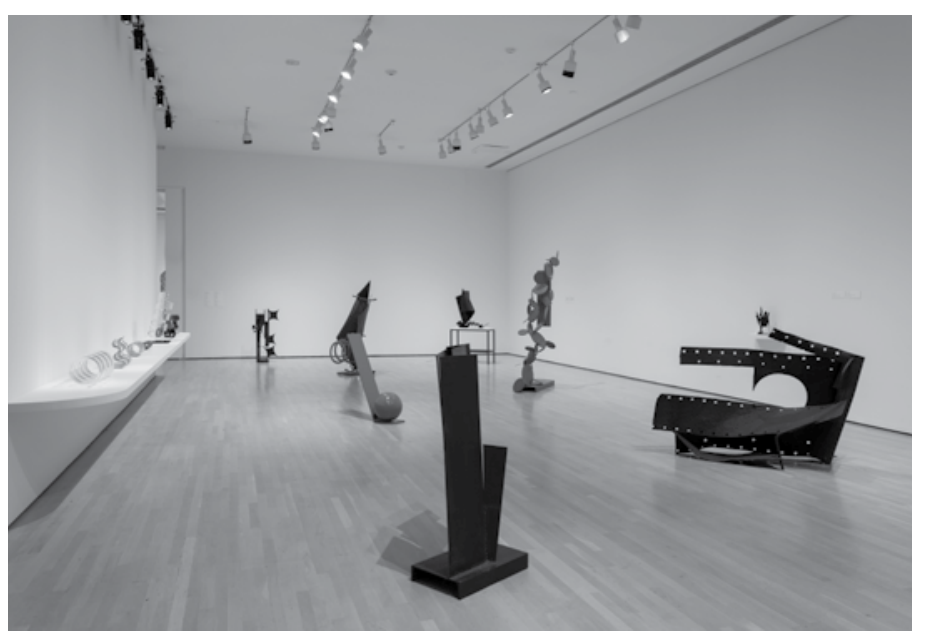

ambitions in wanting to present works from early, middle, and late periods (hence the title: Les automatistes en trois temps). The result was an overview of how these remarkable artists, starting from roughly the same place with roughly the same theories and techniques, went off in different directions and explored quite different modes. Standing in the gallery, at a glance one could see remarkable changes in the work of each artist: how Barbeau, Leduc and Mousseau moved in the direction of more controlled, hard-edged, optical and colour-field effects while Borduas, Riopelle and Ferron maintained the gestural quality of their work; how Pierre Gauvreau played both tendencies off against each other in middle-period paintings; how both Riopelle and Gauvreau, late in their lives, began using spray paint and a variety of objects as stencils, to very different effect. There was talk about what a remarkable show it would be if a large, public gallery could mount an exhibition based on the same idea, but involving more works, and with no restrictions of scale.

More politically and socially historical in flavour was the exhibition Refus global, 70 ans mounted in the entrance and the gallery of the offices of Québecor, the huge Montreal communications company. ${ }^{15}$ On the walls of the cavernous entry to this building hung large paintings from various periods by Françoise Sullivan, Pierre Gauvreau, Marcelle Ferron, and Jean Paul Riopelle. Despite their size, they were difficult to see in this space where the lighting is not good. This was especially true for a large, vertical Riopelle painting stuck on a back wall near the elevators. To see the main exhibition, one proceeded left off the entry hall into a relatively small space, long and narrow, with display cases, small artworks ly to a history of Refus global in the context of 1948 Quebec. There were speakers softly playing voices such as Thérèse Renaud (a performer and writer, signatory of Refus global) reading from Borduas' lead manifesto and Françoise Sullivan reading from " $\mathrm{La}$ danse et l'espoir," her contribution to the publication. The artworks included a delightful, small 1948 painting by Borduas and a set of drawings by Mousseau, Ferron, Barbeau and Gauvreau, flanked by a small watercolour each by Madeleine Arbour and Françoise Riopelle, signatories not known as visual artists. This was one of the attractive qualities of the exhibition: its inclusiveness. All the signatories of Refus global were represented in some way, at least through poster-sized photographs accompanied and photographs devoted essential- with brief biographical sketches. The exhibition itself was not highly attractive or visually memorable, but it may, in fact, have a broader and longer impact than the others l've described because of its placement in a corporate building where crowds of people pass every day, because of its use of large photographs and sound, and especially because of the twenty-page pamphlet (free) that reproduced photographs, biographies, and brief chronologies included in the exhibition, making a printed record available to a potentially large, not necessarily museum-going, general public. We have been used to seeing the museums of Quebec, and even the National Gallery, present important group shows dedicated to the Automatists on anniversary years, but there were none in 2018 (as distinguished from the solo retrospectives discussed here). Was the Québecor exhibition an attempt to fill that gap?

At this point it may seem like back-tracking to return to another exhibition on a single artist-the Françoise Sullivan retrospective at the Musée d'art contemporain de Montréal ${ }^{16}$-but, as I will explain, the theme of group manifestos was made part of a broader programme obviously intended to benefit from the local awareness of Refus global and its anniversary. Before getting there, I would like to give a sense of the part devoted to Sullivan herself, which, although it was not huge in the quantity of works shown, gave a thoughtful overview of the astonishing diversity of this artist's expressions. Besides the main halls showing paintings and sculpture, along with videos of dance and other performances, there were two important rooms on each side of the main entrance. One had the customary display cases with printed documents (invitations to exhibitions, small posters, photographs, artist's notes), as well as an intelligent half-hour documentary on Sullivan done for Femme d'aujourd' hui on Radio-Canada television in 1979. This room, and another full of screens 
showing audio-visual documents mostly related to dance, as well as a long table with books for essential reading, were examples of how the staff of the museum had worked to present a wide range of information, not always tidy, not always pretty, but very informative for anyone willing to take the time. One could stand in the middle of that video room and watch three versions of Sullivan's early choreography, Dédale, danced by three dancers over thirty years; or an entire set of early dances by Sullivan and Jeanne Renaud, performed in 1988 as part of the fortieth anniversary of Refus global; or a film of Luis Jacob romping mostly naked in the snow, performing A Dance for Those of us Whose Hearts Have Turned to Ice (2007), in homage to (or parody of?) the famous Danse dans la neige.

The main halls provided an overview of the artist's work from figurative portraits done in the early 1940 s, through the round, unstretched canvas tondos and the figurative return in the 1980 s, to the monochromes of the new century and eventually the large checker-boards of colour done in the past few months. Along with these, and the sculpture, were photographs and constructions and films relating to her conceptual period of the 1970 s, a part of her work only recently getting the attention it deserves. For example, I was pleased to watch a short film I had missed: Dégrangolade, showing the blocking and unblocking of windows during an intervention with David More on the Blasket islands of west Ireland in 1978. But in this plethora, the piece I found most exciting was the Rideau sonore $(2 \times 5$ metres $)$ that Sullivan created for a choreography by Jeanne Renaud in 1965 . I had seen pictures of Renaud and Peter Boneham moving through and among the multi-shaped hanging metal pieces that provided the acoustics for this dance-but I had never seen the iron curtain itself, since it had been stored for more than fiftyyears. It is a magnificent object in its own right, a kind of over-sized Calder with performance possibilities on its mind.

At first glance, the Sullivan retrospective may appear to be an artist-specific exhibition, with minimal reference to Refus global and the history of Automatism, but in fact the MACM came around to our topic in a fascinating and surprising way, by running two exhibitions simultaneously with the Sullivan retrospective, each relating to manifestos written internationally over 150 years. The first was a reprise of a 2015 video installation by German artist Julian Rosefeldt, entitled Manifesto. ${ }^{17}$ Entering into a large, darkened room, spectators were confronted with a grouping of 13 two-sided screens, each with a bench in front, with room to move freely from one to the other. All showed what might be called vignettes, each involving the actress Cate Blanchette in various lushly-filmed situations, costumes, and settings while she or a voice-over recited fragments from manifestos written by social activists or artists from Marx to Lars von Trier by way of Dada, Futurism, Surrealism, Situationism and Fluxus, to name a few. The relationship between word and image, text and action, was as puzzling and disturbing as were the original manifestos. For example, in the scene identified with Situationist manifestos, Blanchett is a homeless man dragging his belongings through a desolate cityscape of garbage and ruined buildings; in the scene identified with film, she is a teacher in a classroom of children writing an exam; in the one identified with Fluxus, Merz, and performance, she is a choreographer with a Russian accent putting futuristic dancers through their paces; in another, she is a female maker of marionettes, and she holds one resembling herself as she speaks fragments from the Surrealist manifestos. What to make of this? What is Rosefeldt doing with the texts he invokes, and what is his intention? Is this a mockery of manifestos, showing them as outdated verbiage in a socially, politically, and artistically changed world? Is it just a dumbing down, attracting audiences of popular culture (which it was certainly doing on the evening I was present) through the lure of film and a well-known star? Is it complex and complicated art cinema at its beautiful best? Such questions are beyond the scope of this article, but there is one we might ask: what did it all have to do with Refus global, the Automatist movement, and the retrospective next door? On the face of things, not much. In 2015, Rosefeldt had likely never heard of an avant-garde in Quebec. He certainly made no reference to any in Manifesto. Hence the need for a kind of bridging exhibition to form a conceptual and physical link between Sullivan and Rosefeldt. This was the rôle of Partitions, ${ }^{18}$ an "exposition documentaire" that showed not only hard copy originals of most of the manifestos (often beautiful objects in their own right) referenced in Rosefeldt's installation, but also Refus global with Sullivan's contribution, "La danse et l'espoir," along with local offerings such as Prisme d'yeux (a rival statement by Pellan, de Tonnancour and others), as well as later pronouncements by such groups as the Plasticiens. One could actually walk from the Sullivan retrospective through the Partitions corridor and into the audio-visual world of Manifesto-or vice versa, as the spirit moved. In the final analysis, it was a richly varied experience that broadened the context of each part.

Looking back over what I witnessed in 2018, it's fascinating to note how different events bounced off and complemented each other-for example, how the Barbeau and Sullivan retrospectives resonated with the smaller group shows that were happening almost simultaneously. I have no doubt that an important energizing force behind all this was the continuing relevance of the history of Automatism for Montrealers. I only wish there were a similarélan in Toronto. 
Ray Ellenwood, Professor Emeritus and Senior Scholar at York University in Toronto, is an awardwinning translator and author of Egregore: A History of the Montréal Automatist Movement. In 1998, he organized a symposium, exhibition, and concert at York University to celebrawte the fiftieth anniversary of Refus global, and he continues to write and publish extensively about the Automatistes.

_rayellen@yorku.ca

1. For a much more detailed account than I can offer here, see Sophie Dubois, Refus global, Histoire d'une réception partielle (Montréal: Les presses de l'université de Montréal, 2017), or FrançoisMarc Gagnon's Chronique du mouvement automatiste québécois, 1941-1954 (Montréal: Lanctôt Éditeur, 1998).

2. See, for example, Philippe Dubé, «Quand le culte occulte, » Le Devoir, July 8, 1998.

3. As a sign of the general acceptance of Refus global as a historically important document, consider the fact that Françoise Sullivan, one of the signatories, was invited to read from the text during celebrations in Quebec City to mark the 250th anniversary of the battle of the Plains of Abraham (see Jérôme Delgado, "Borduas, héros oublié?", Le Devoir, February 20, 2010.)

4. Borduas, les femmes automatistes et Refus global, at the BAnQ Vieux-Montréal, September 11,18 and 25 from 13:30 to 15:30.

5. François-Marc Gagnon et l'histoire de l'art au Québec, held at the Musée de l'imprimerie du Québec on October 19, from 9:00 to 14:30. [Editor's note: Professor Gagnon died March 28, 2019. See the memorial note in this issue.]

6. La tendresse des nuages (Fernand Leduc), Galerie Catalogue, Montréal, August 25 to November 10, 2018. Curator: Pierre Bourgie.

7. Marcel Barbeau: en mouvement, Musée national des beaux-arts du Québec, October 11, 2018 to January 6, 2019. Curator: Eve-Lynne Beaudry. 240-page catalogue.

8. This part of his work is well described by Rober Racine in "Danser la peinture," one of the essays included in the catalogue of the exhibition.

9. Not surprisingly, that exhibition made little or no mention of Riopelle's Automatist past, in part because he himself tended not to give it much importance, but also because it was not relevant to the period of his relationship with Joan Mitchell.

10. Françoise Sullivan, The modern.toronto, Toronto, September 20 to November 17, 2018. Curator: Paul Bradley.

11. We have since learned that this gallery is closing, which is a shame because it was certainly an attractive exhibition space.

12. Françoise Sullivan, Galerie Simon Blais,

Montréal, October 10 to November 24, 2018. Curator: Paul Bradley. No catalogue.

13. Refus global-70ième anniversaire, Galerie Simon Blais, Montréal, September 6 to October 6 , 2018. No catalogue.

14. Les Automatistes en trois temps, Galerie Michel Guimont, Montréal, September 23 to October 23, 2018. 36-page catalogue.

15. Refus global: 70 ans, Québecor espace musée, Montréal, October 2, 2018 to lanuary 9. 2019. Curators: Simon Blais, Paul Bradley, Claude Gosselin. 24-page catalogue.
16. Françoise Sullivan, Musée d'art contemporain de Montréal, October 20, 2018 to January 20, 2019. Curator: Mark Lanctôt. 286-page catalogue.

17. Julian Rosefeldt, Manifesto. October 20, 2018 to January 20, 2019. Curator: Lesley Johnstone. No catalogue.

18. Partitions, October 20, 2018 to January 20,2019 . Curator: François LeTourneux. No catalogue.

\section{Leah Modigliani}

Engendering an Avant-Garde:

The Unsettled Landscapes of Vancouver Photo-Conceptualism

Manchester: Manchester University

Press, 2018

296 pp. $41 \mathrm{~b} /$ willus.

E 80 (hardcover) ISBN 9781526101198

Christine Conley

In Engendering an Avant-Garde, Leah Modigliani examines the absence of women artists in Vancouver photo-conceptualism, from its inception in 1968 to its identification as the "Vancouver School," a global brand that emerged in early 1990 s writing about Jeff Wall and lan Wallace and variously encompassed Ken Lum, Christos Dikeakos, Rodney Graham, Roy Arden, Arni Haraldsson, and Stan Douglas. Modigliani positions this self-declared vanguard within a critical discourse generated by the likes of Andreas Huyssen, Johanne Lamoureux, T. J. Clark and Griselda Pollock, who have revealed how the historical avant-garde perpetuated patriarchal privilege through dichotomous thinking (the feminine as alterity) that situated "women or others as oppositional to the mission of a self-selective male group identification."(9) Her study considers how this dynamic was manifest in Vancouver photo-conceptualism. Male artists, consciously engaged with the concerns of the historical avantgarde, explored social alienation in the urban landscape in the absence of female agency, yet maintained images of women in their work. How did this happen during a period of feminist political and cultural agitation?

While this question forms the crux of the text, successive chapters elaborate an extended discourse analysis of how international critical acclaim has embraced Vancouver photo-con-

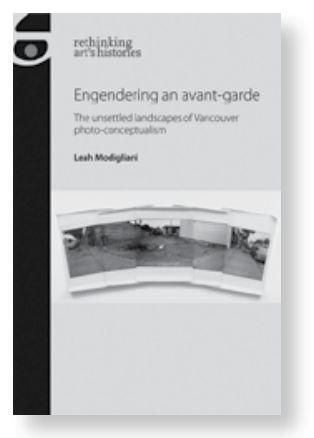

ceptualism as a continuation of European investments in and perspectives on the modernist avant-garde-with frequent analogies to nineteenth century French painting, for instance, in the case of Jeff Wall-rather than considering how the specificity of Vancouver production might illuminate the global possibilities for that project as a social process. Modigliani claims this exclusionary dynamic parallels the "exclusionary structure of settler colonial populations' need to control territory," hence her understanding of art discourse as a "transfer narrative" (17) linked specifically here to the absence of local inhabitants, including Indigenous peoples, in the "defeatured" landscape of Vancouver photo-conceptualism.

The first chapter focuses on Wall's early transparencies Picture for Women (1979) and The Destroyed Room (1978) to consider how the feminist content of these works was overlooked due to the hegemony within art history of "patriarchal experiences of public space and theoretical knowledge production" (16) over feminist critical approaches, such as Laura Mulvey's "Visual Pleasure and Narrative Cinema." Reviewing analyses of these works by prominent critics Donald 